\title{
Daratumumab Regimen
}

National Cancer Institute

\section{Source}

National Cancer Institute. Daratumumab Regimen. NCI Thesaurus. Code C160019.

An immunotherapy regimen consisting of daratumumab that may be used in the treatment of plasma cell (multiple) myeloma. 